\title{
VALUING DELIBERATE BUILT-IN FLEXIBILITY IN HOUSES - EXAMPLED
}

\author{
David G. CARMICHAEL ${ }^{1, *}$, Reza TAHERIATTAR ${ }^{1}$ \\ ${ }^{1}$ School of Civil and Environmental Engineering, The University of New South Wales, \\ Sydney NSW 2052, Australia
}

Received 22 February 2017; accepted 26 December 2017

\begin{abstract}
Housing requirements commonly transition over time, and there are financial, social and environmental impacts associated with altering and moving houses. With possible future alteration in mind, this paper looks at the viability of deliberately incorporating flexibility into houses at the time they are designed and built, as compared with no specifically incorporated flexibility (yet still possibly capable of being altered). A comparative analysis, rather than an absolute analysis, is outlined. The financial viability is performed as an options analysis, while the social and environmental matters are evaluated along life cycle assessment lines. As a case example, the paper considers the viability of incorporating deliberate two-storey flexibility into a single-storey house using Australian practices. It is shown on the case example that incorporating deliberate built-in flexibility can perform positively against all sustainability criteria - financial, social and environmental, separately or combined - however the generality of this conclusion remains to be proven.
\end{abstract}

Keywords: changeable houses, deliberate built-in flexibility, options analysis, valuation, flexibility.

\section{Introduction}

Flexibility is seen as an important issue within modern commercial and residential buildings, as the needs and wants, real and perceived, of the user change over time (Gann \& Barlow, 1996; Heath, 2001). Flexibility or adaptability here refers to a capability to be changed in line with future circumstances. With houses, the needs and wants of users change in line with their lifestyle and employment/ income/family/schooling situation and social factors generally (Kendall, 1999; Schneider \& Till, 2005). However, at least within the Australian context, traditional detachedstyle houses are built for a single purpose, which suits the owner at the time. As families grow/shrink, house owners look for more/less space (ABS, 2011, 2012). This might be accomplished by relocating to another neighbourhood or, if this is not desired, converting the current house, including the undertaking of alterations and additions, with the extreme being complete demolition and replacement. Such practices represent a significant sustainability issue. ABS (2011) gives that $27 \%$ of people over 15 have lived in their houses for more than 15 years, 30\% have lived in the same house for 5-14 years and $43 \%$ of people moved in the previous 5 years. This could imply, subject to viability, that there may be a need in the market for houses with deliberate in-built flexibility.
The architecture literature acknowledges a need for flexibility within building infrastructure, in order to delay obsolescence - physical, economic, functional, technological, environmental, social, or legal (Gann \& Barlow, 1996; Slaughter, 2001; Schneider \& Till, 2005; Till \& Schneider, 2005; Greden, 2005; Wilkinson, James, \& Reed, 2009; Gosling, Sassi, Naim, \& Lark, 2013). However, the literature stops short in valuing deliberate built-in flexibility (Gann \& Barlow, 1996; Moffatt \& Russell, 2001; Slaughter, 2001). This paper provides a methodology for valuing deliberate built-in flexibility. It does this in financial terms through a real options analysis (Carmichael, Hersh, \& Parasu, 2011), while the social and environmental matters are evaluated along life cycle assessment lines. Financial, social and environmental considerations are looked at singly and combined. A case example involving a single-storey house converted to two storeys is given. Conversion is done in response to changes in house usage and house requirements over time. It is acknowledged that other forms of alteration are possible, and that housing practices are location-dependent, leading to too many variables to enable any generalisation. However, the methodology given in this paper is general; it carries over to other situations and locations, but the actual numbers used and building practices described in the case example do not.

*Corresponding author. E-mail: D.Carmichael@unsw.edu.au 
Two forms of alteration (denoted A and NA here) are considered and compared with respect to detached-style houses (not apartment buildings):

A form. Where flexibility features have been deliberately designed and built in $a b$ initio, with the view that alteration may (but not necessarily) take place in the future depending on future circumstances.

NA form. Where a house has been designed and built without flexibility features in mind, but where future alteration may still be fortuitously possible, albeit with greater thought and effort.

The paper will be of interest to people within the housing and construction industries, as well as house owners. Through the approach given, it is possible to gauge the viability of including specific and deliberate built-in flexibility in any design and construction. It is emphasised that the paper refers to the adaptability of traditional housing, and not to the conversion of other building types, such as offices or warehouses, to housing, though the paper's methodology can also be applied to these other building types.

The paper firstly provides a review of literature on changed usage and changed demand. A case example is presented and deliberate built-in flexibility valued, and an argument on the viability (broadly from a sustainability viewpoint) of deliberate built-in flexibility given. Apart from the case example, the paper does not look at the specifics of design or construction, but rather the valuation based on design concepts. Nor does it examine any constraints on building design or work that may be imposed by government regulations.

The paper's approach to establishing the viability of deliberate built-in flexibility within houses is original.

\section{Background}

House conversions may be with respect to interiors, exteriors, house volume (or space) and use (Till \& Schneider, 2005). The literature on this is predominantly with respect to established houses, designed and built without forethought to alteration (NA form). By contrast this paper scrutinises deliberate built-in flexibility (A form).

\subsection{Typical alteration - NA form}

Changing interiors includes reconfiguring space layout from closed individual spaces to open-plan spaces, or vice versa (Greden, 2005; Till \& Schneider, 2005). This alteration aims to enhance space usage efficiency, reusability of spaces, and take advantage of existing space potential to accommodate minor changes in needs. Common practice involves a rearrangement of rooms by relocation of interior partitions, with associated modification in ceiling and floor finishes (Friedman, 1993; Moffatt \& Russell, 2001; Till \& Schneider, 2005).

Changing volume or space may be in response to an increase or reduction in demand. House expansion might occur either vertically or horizontally (Remøy, de Jong, \&
Schenk, 2011). House volume contraction might be carried out, for example, through dividing and possibly subletting a part of the house space.

Examples of changing use, which might be referred to as "adaptive reuse" (Langston, 2011; Conejos, 2013), include: refurbishing heritage buildings following obsolescence in terms of their original use (Greden, 2005; Langston, Yung, \& Chan, 2013); and converting redundant offices into apartments, perhaps because of an oversupply of office space, changing technology or changing demands (Gann \& Barlow, 1996; Heath, 2001; Wilkinson et al., 2009; Remøy et al., 2011). However, such changes are less relevant to houses than commercial buildings (Wilkinson, 2011), except for the incorporation of new technology, or change in usability due to a life transition of the owner. Examples of this include making houses accessible throughout and more readily usable for aged people, particularly in bathroom and kitchen areas (Fänge \& Iwarsson, 2005; NCSU, 2013).

\subsection{Flexibility: built-in (A) form}

Much less literature on A form alteration exists compared to the NA form (Gann \& Barlow, 1996; Heath, 2001; Langston, Wong, Hui, \& Shen, 2008; Langston et al., 2013; Wilkinson et al., 2009).

There is a belief, but generally not supported with analysis, that it is inefficient to construct buildings with a single use in mind; rather, there is a need to design buildings with the ability to change if necessary (Gann \& Barlow, 1996; Kendall, 1999; Slaughter, 2001). Kendall (1999) talks of open buildings, where the façade is the only thing that changes, and easily accessible building services. Kendall (1999) suggests that designing infrastructure with the foresight for change will not cost much more in original outlay. Slaughter (2001) suggests that design for flexibility entails: physically separating major building systems and their subsystems; prefabrication of major system components; and designing certain systems significantly over capacity to meet future demand. With such an approach, Slaughter (2001) suggests that the total building cost would only increase by $1 \%-2 \%$, and this is regarded as insignificant when considering that the building may be obsolete if demand changes.

The notion of built-in flexibility overlaps with that of the "universal design" concept (Karol, 2007; NCSU, 2013; Palmer \& Ward, 2013), where a house is designed and built as user-friendly to all persons, including the disabled, young and old. The universal design concept addresses the changing needs of users. However, unlike this paper's view on flexibility, it does not have a future time at which the design is changed; rather the design stays constant over the life of the dwelling. NCSU (2013) suggests that such designs will only add small extra costs, and could benefit in terms of longevity of owner's usage, and expanding the tenant pool if applied to rentable houses.

Moffatt and Russell (2001) break down alterability into a number of approaches, which can be achieved through 
changes in design, namely: flexibility in space layout; convertibility in space use; and expandability in volume. Such design is suggested to lead to longer service lives because changes can be achieved at lower cost. In a similar way, Arge (2005) looks at alterability in terms of generality, flexibility and elasticity, which relate to the physical design of the building to meet changed needs.

Comments on incorporating flexibility in design are given by Guma (2008) and Zhang (2010) and Carmichael (2015). de Neufville and Scholtes (2011) suggest moving away from conventional design based on fixed specifications. Schneider and Till (2005) and Till and Schneider (2005) comment on the trade-off between possible upfront extra costs and long-term benefits, and the architectural and engineering aspects of flexible design.

\section{A versus NA comparative analysis}

\subsection{Outline}

The analysis here is given in general terms, which can be applied to any deliberate built-in flexibility situation. A later case example puts specific numerical values to the analysis.

Two forms of alteration (A - deliberate built-in flexibility that facilitates alteration, and NA - no built-in flexibility, the more usual practice) are considered and compared in financial, environmental and social terms, singly and combined. The analysis considers a house (built at time $\mathrm{t}=0$ ), with the potential to be altered, at some time $\mathrm{t}=\mathrm{T}$ in the future. There is a trade-off between financial, environmental and social impacts now and those in the future. The alteration, however, need never occur, depending on the house owner's situation in the future. That is, the alteration is discretionary or an option. The time, T, can be varied in the calculations in order to show the relationship between time of any alteration and flexibility value.

\subsection{Financial analysis}

Existing publications do not put a financial or any quantitative value on deliberate built-in flexibility, or use financial market analogies which have been criticized (Gann \& Barlow, 1996; Heath, 2001; Slaughter, 2001; Carmichael et al., 2011). Conventional discounted cash flow analysis and decision trees are not applicable because of the uncertainties present and because the alteration may or may not take place at the discretion of the house owner. Here the financial value is established through a rational real options analysis based on cash flows (Carmichael et al., 2011; Carmichael, 2016a).

An option represents a right but not an obligation. Depending on future circumstances, that option may or may not be exercised. Generally, it would only be exercised if it was worthwhile to do so, and not exercised if not worthwhile to do so. That is, having an option caps any downside involved at the initial cost to build in flexibility, but rewards any upside involved. This upside, when discounted to time $t=0$, gives the value of the option. The option is described as "real" because it deals with something physical, by comparison with "financial" options, which deal with underlyings such as stock or carbon prices.

To establish the option value (but not the complete financial viability), only costs at $\mathrm{T}$ are taken into account. (For ease of discussion, negative benefits are also labelled as costs. Positive benefits are assumed to be the same for both the A and NA forms.) Expected values, $E[$ ], and variances, $\operatorname{Var}[]$, of all costs for both A and NA forms at $\mathrm{T}$ are estimated, or if they occur beyond $\mathrm{T}$, are discounted to $\mathrm{T}$. There are a number of ways by which estimates may be handled. Here, optimistic (a), most likely (b) and pessimistic (c) values are estimated as is done in the planning technique PERT. This leads to: expected value or mean = $(a+4 b+c) / 6$, and variance $=[(c-a) / 6]^{2}($ see for example, Carmichael, 2006). Because estimates for the A and NA forms are based on similar assumptions, it could be anticipated that there would be very strong correlation between the estimates for the A and NA forms.

To ascertain the value of flexibility (A form) compared with conventional practice (NA form), the difference between the NA and A forms is examined. Let $X_{T}$ be the net cost at time $\mathrm{T}$. That is,

$$
X_{T}=N A_{T}-A_{T},
$$

where: $N A_{T}$ and $A_{T}$ are the costs, at $\mathrm{T}$, of the NA and $\mathrm{A}$ forms respectively. Then,

$$
\begin{aligned}
& E\left[X_{T}\right]=E\left[N A_{T}\right]-E\left[A_{T}\right] \\
& \operatorname{Var}\left[X_{T}\right]=\left(\sqrt{\operatorname{Var}\left[N A_{T}\right]}-\sqrt{\operatorname{Var}\left[A_{T}\right]}\right)^{2} .
\end{aligned}
$$

These are discounted to give the present worth, $P W$,

$$
\begin{aligned}
& E[P W]=\frac{E\left[X_{T}\right]}{(1+r)^{T}} \\
& \operatorname{Var}[P W]=\frac{\operatorname{Var}\left[X_{T}\right]}{(1+r)^{2 T}},
\end{aligned}
$$

where: $r$ is the interest rate. Calculation of the flexibility value follows,

$$
\text { Flexibility value }=\Phi M,
$$

where: $\Phi=\mathrm{P}[P W]>0$ and is termed the investment feasibility (Carmichael \& Balatbat, 2008); P is probability, and $M$ is the mean of the present worth upside measured from $P W=0$. To calculate $\Phi$ and $M$, and knowing $E[P W]$ and $\operatorname{Var}[P W]$, any distribution can be fitted to $P W$, but it is anticipated that most people would use a normal distribution (Carmichael, 2016a).

This flexibility value is then compared with the cost of building in flexibility at time 0 . Financial viability is established for flexibility when the flexibility value exceeds this initial cost. However, where an owner has restricted access to finance at time 0 , or wishes the cheapest initial cost house, this may constrain the owner from investing in flexibility. 


\subsection{Environmental analysis}

Environmental adaptability issues have recently started to be valued quantitatively (Moffatt \& Russell, 2001; Langston, 2013; Conejos, 2013). de Jonge (2005) provides an in depth commentary on eco-cost comparisons between new construction, extensive renovation, refurbishment and continued operation of residential buildings. In this paper, life cycle assessment (LCA) analysis is preferred as being the most applicable approach (ISO, 2006; Moon, Hyun, \& Hong, 2014). The analysis looks at the environmental impacts at times $\mathrm{t}=0$ and $\mathrm{T}$, assuming impacts between $\mathrm{t}=0$ and $\mathrm{t}=\mathrm{T}$ and subsequent to $\mathrm{T}$ to be the same for both A and NA forms. Should these assumptions not be so in particular cases, the differences can be included in the analysis.

Environmental issues involved in deconstruction and construction (at $\mathrm{t}=0$ and/or $\mathrm{t}=\mathrm{T}$ ) include (Moffatt \& Russell, 2001):

- Resource consumption: materials and energy use.

- Emissions: equipment-producing emissions; embodied emissions within materials used or removed.

- Waste generation: material waste in deconstruction and construction; material reuse.

This list is not exhaustive, and would be tailored to each specific case. When compared to full house demolition, the contribution of flexibility to sustainability through saved resources and energy is acknowledged, among other instances, through the quotation: the greenest buildings are the ones we already have (Langston et al., 2013, p. 234, after Jacobs).

A well-designed A form house leads to the reuse of materials and a subsequent reduction in the environmental impact in terms of waste, materials consumption, embodied energy and emissions (Kats, Alevantis, Berman, Mills, \& Perlman, 2003). A well-designed A form house also leads to lesser construction site time and effort in the alteration (Gosling et al., 2013). The flow-on is reduced construction energy use and emissions (Hong, Ji, Jang, \& Park, 2014), and nuisance related dust and noise.

\subsection{Social analysis}

Social adaptability issues have recently started to be valued quantitatively (Moffatt \& Russell, 2001; Langston, 2013; Conejos, 2013); in this paper, social life cycle assessment (SLCA) analysis is preferred as being the most applicable approach (Lehmann, Zschieschang, Traverso, Finkbeiner, \& Schebek, 2013; Surbeck \& Hilger, 2014). SLCA follows the approach of environmental LCA in assessing social issues, except for those issues such as people flow within the house, and aesthetics, which might be analysed based on surveys of stakeholders' opinions. Guidelines and a useful explanation of SLCA are given by UNEP/SETAC (2009). These guidelines are consistent with the ISO 14040 and 14044 (ISO, 2006) standards for Life Cycle Assessment, but adapted to social issues. A two-fold classification of social impacts - by stakeholder categories and impact categories - is used, along with subcategories containing social concerns.

Social issues, associated with altering houses, result from the physical and/or psychological impacts on stakeholders (Surbeck \& Hilger, 2014). Those social issues connected with deconstruction and construction reflect the quantity and type of physical work involved in the alteration. The A and NA forms require differing extents and type of work activities at $t=0$ and $T$. This, in turn, leads to differing extents of the social issues. Some relevant social issues (at $\mathrm{t}=0$ and/or $\mathrm{t}=\mathrm{T}$ ) include:

- Workers: health and safety in construction; employment opportunities (Sawacha, Naoum, \& Fong, 1999; Edwards \& Turrent, 2000).

- Neighbours: disruption to traffic in the immediate neighbourhood (Gilchrist \& Allouche, 2005); emitted pollutants, dust, noise and vibration (Gilchrist \& Allouche, 2005 after Bein).

- Owners: level of comfort; identity due to long-term inhabitancy (Guma, 2008); inconvenience due to compulsory move-out (Edwards \& Turrent, 2000).

This list is not exhaustive, and would be tailored to each specific case. The potential for increased accidents (and hence lower safety), and greater disturbance and inconvenience to the owner, neighbours and local traffic flow, is associated with increased construction site-based activities (Sawacha et al., 1999). However, shorter site times could be anticipated to lead to lesser total employment hours (Edwards \& Turrent, 2000).

\section{Case example: single- to two-storey house conversion}

A case example involving a single- to two-storey house conversion, utilizing the methodology of Section 2, follows. Creative design is involved in how flexibility might be incorporated in order to produce the best outcome for the owner. The following analysis makes certain design assumptions, and these relate to one style of building and material choice, but readers may be able to develop better design concepts, or prefer other materials. The analysis is also based on building practice assumptions and industry knowledge and, while applicable to the case example, may not apply in other situations. Accordingly, the methodology of Section 2, rather than the absolute design and associated numbers, is emphasised in the paper. The numbers are indicative, but will change with different reader assumptions, and geographical locations different to that of the authors.

In new house construction, cheapest cost concerns of the buyer can lead to houses with preset designs, where the builder can gain economies of scale through replicated production. Such houses may be adequate for immediate needs, but not necessarily for future enlarged space needs. This is the case example considered here. House size selected is average for the market. 


\subsection{Design and construction}

The initial construction is a single-storey house, as may be seen in countries such as America, Canada, Australia and New Zealand, but to a much lesser extent in European countries with different land pricing and regulations. The main structural elements to be considered are the foundations, roofing, walls and upper storey flooring.

Possible approaches are that the new construction sits on top of the old, or that the old is raised in total by jacking and placing the new underneath, provided the original design and construction makes this possible. The former practice is adopted here, however the overall analysis of Section 2 and considerations for both situations are the same.

Base design assumed. The following gives the base designs analysed, with other possible variants mentioned.

Foundations - strip concrete footings, with a concrete slab overlay. Existing estimating practices suggest that the extra cost of increasing the size of the footings and slab depth in going to a two-storey design, over a single-storey design, is small. (Other method variants for house foundations include strip footings, footing slabs, stiffened or waffle raft slabs, and concrete piers or piles.)

Roofing - with flexibility in mind, prefabricated timber trusses, which are able to span between external walls if required, are selected over conventional timber struts and beams. Trusses allow for internal room flexibility, and so-called "open plan living". A truss might be re-used in whole or re-assembled in parts (Reardon, 2013) in going from a single-storey house to a two-storey house, however deconstructing and reconstructing a roof is not straightforward, due to the deformation and warping of timber roof trusses caused by heating and cooling. Pitching a roof by using timber struts and beams relies on internal load bearing walls. (Steel-framed roofs with suitable choices of fasteners might also be used.)

Internal/external walls - timber-framed. For timber stud walls, the main difference between single-storey and two-storey timber-framed houses is the wall stud size. The assumption in the following is that both the deliberately built-in A form, and non built-in NA form, walls are sufficient to carry an upper storey, and hence the wall costing is the same and can be omitted from the calculations. Should this not be so, then the difference in wall costs would be included in the calculations. (Other method variants include brick or steel-framed walls.)

Upper storey flooring - with flexibility in mind, the ceiling for the single storey house is constructed as a floor for the potential upper storey. This requires using more substantial beams than would ordinarily be used for ceilings, together with flooring boards or floor sheeting. By doing this, the lower storey remains habitable throughout alteration, avoiding unpleasant moving and temporary rental elsewhere, and creates less disruption (including services and amenities) and dust. For the non built-in NA form, timber infills and timber beams sitting on these are used such that the upper storey flooring can be built with- out disrupting the existing ceiling. This does however lead to a noticeable distance between the lower storey ceiling and the upper storey floor, which may be aesthetically undesirable in locations such as stairwells and in viewing the external house proportions. Also, it is generally the view that while this construction is taking place, the house is not habitable, requiring temporary vacating and rental of an alternative dwelling by the owner. The intangibles associated with any temporary relocation of the owner would be difficult to assess accurately.

The above outlines the engineering aspects of the designs. Other considerations relating to the architectural design of the original and modified dwelling, including people movement, room juxtapositions, external access, stairwells and so on are assumed to be in hand. The separation and recycling of used building materials is assumed as adopted practice.

\subsection{Financial analysis}

Table 1 summarises the differences that are costed in this paper's analysis. Costing estimates follow Cordell (2014) and Rawlinsons (2015) based on quantity take-offs from drawings, together with quotations from various builders, engineers, tradespeople and industry representatives.

Based on the above-given assumptions and approach, cost estimates give the following: $E\left[N A_{T}\right]=\$ 69.9 \mathrm{k}, \operatorname{Var}\left[N A_{T}\right]=$ $(\$ 5.4 \mathrm{k})^{2} ; E\left[A_{T}\right]=\$ 26.2 \mathrm{k}, \operatorname{Var}\left[A_{T}\right]=(\$ 2.0 \mathrm{k})^{2}$. Figures 1 and 2 show the change in flexibility value with $\mathrm{r}$ and $\mathrm{T}$. For all

Table 1. Case example. Built-in versus non built-in forms differences only given

\begin{tabular}{|l|l|l|}
\hline \multicolumn{1}{|c|}{ Time } & \multicolumn{1}{|c|}{ A - Built-in form } & NA - Non Built-in form \\
\hline $\mathrm{t}=0$ & $\begin{array}{l}\text { Construct upper storey } \\
\text { timber floor }\end{array}$ & Construct ceiling \\
\hline $\mathrm{t}=\mathrm{T}$ & Disassemble roof & $\begin{array}{l}\text { Demolish roof } \\
\text { Construct upper storey } \\
\text { timber floor } \\
\text { Construct roof } \\
\text { Reassemble (salvage, roof }\end{array}$ \\
\hline
\end{tabular}

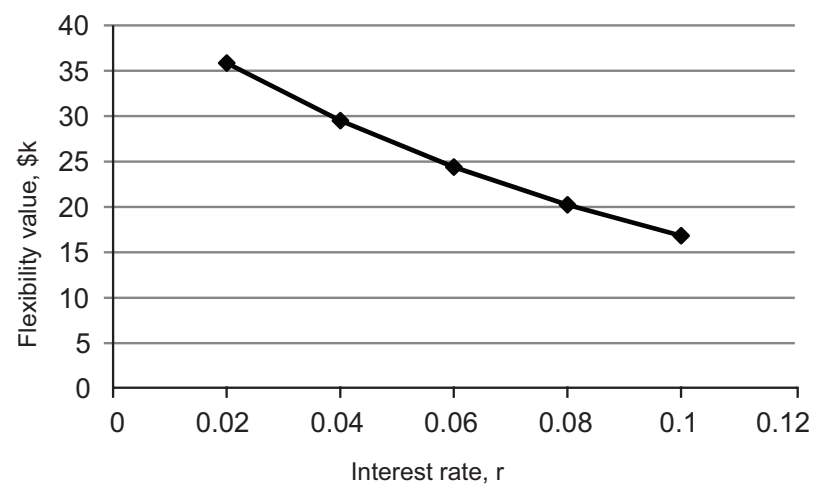

Figure 1. Case example - change in flexibility value with interest rate (per annum). $\mathrm{T}=10$ years 


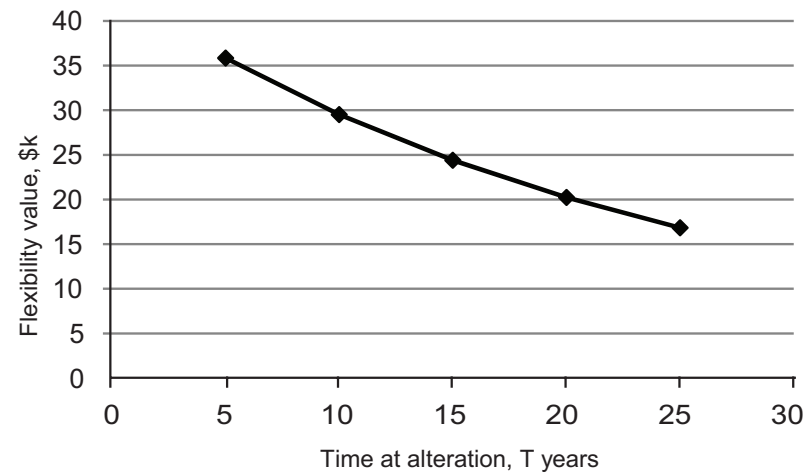

Figure 2. Case example - change in flexibility value with time at alteration, T. $r=0.05$ per annum

calculations, $\Phi$ is very close to 1 implying that the flexibility value is very close to $E[P W]$. The initial investment in deliberate built-in flexibility is estimated as $\$ 28.6 \mathrm{k}$.

The built-in A form is seen to be financially better than the non built-in NA form for lower $r$ and lower $T$ values, and within time periods where people typically look to extend their house space. This is mainly due to a large saving in the A form alteration cost, with no need for upper storey flooring and the partial reuse of existing roof trusses. However, since the initial cost and $E[P W]$ are close, house owners may prefer to keep their initial borrowings as low as possible, may not be encouraged to build in flexibility, and may require an enhanced incentive (for example, positive environmental or social impacts) for investment in deliberate built-in flexibility.

\subsection{Environmental analysis}

Environmental issues that are regarded in this case example as being different between the A and NA forms are noted in Table 2. In other situations there may be different lists, but their evaluation would be along similar lines to those presented here; it is the methodology, not the numbers, which is being emphasized here.

Inventory flows, consisting of materials and energy (environmental inputs); and emissions and solid wastes (environmental outputs), are tracked for the determined unit processes of construction and deconstruction at times 0 and $\mathrm{T}$ (Figure 3 ).

Using data from RSMeans (2015), together with information from builders, engineers, tradespeople and industry representatives, the estimates of differences in inventory flows between the A and NA forms follow. Timber is the predominant material used. The environmental impact flows are summarised in Table 3; the background assumptions are not included here because of space limitations, but they available from the authors. The environmental impact categories are taken here to be the same as the inventories, and are consistent with those adopted in rating systems such as NABERS or Green Star (Rawlinsons, 2015).

It is seen that the $\mathrm{A}$ form performs better with respect to all environmental impacts considered, and hence when
Table 2. Comparison of environmental issues

\begin{tabular}{|l|l|l|}
\hline Time & \multicolumn{1}{|c|}{ A - Built-in form } & NA - Non Built-in form \\
\hline $\mathrm{t}=0$ & $\begin{array}{l}\text { More solid waste; more } \\
\text { material use; longer } \\
\text { construction time - } \\
\text { embodied energy, } \\
\text { emissions, noise }\end{array}$ & $\begin{array}{l}\text { Non-reusable roofing } \\
\text { More solid waste - } \\
\text { existing house materials } \\
\text { and new construction; } \\
\text { more material use; } \\
\text { longer construction } \\
\text { time - embodied energy, } \\
\text { emissions, noise }\end{array}$ \\
\hline $\mathrm{t}=\mathrm{T}$ & Part reusable roofing \\
\hline
\end{tabular}

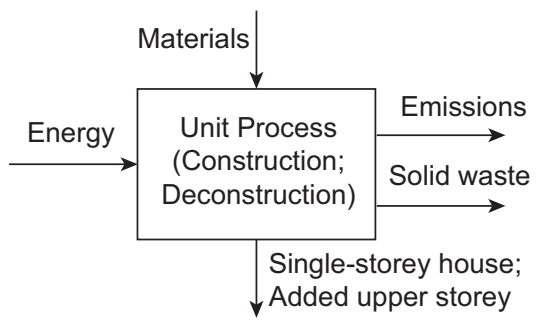

Figure 3. Unit processes and inventory flows for the LCA

Table 3. Differences (NA - A) in environmental impacts

\begin{tabular}{|l|c|c|c|}
\hline Environmental impact & At $\mathrm{t}=0$ & At $\mathrm{t}=\mathrm{T}$ & $\begin{array}{l}\text { Combined } \\
\mathrm{t}=0 \text { and } \mathrm{T}\end{array}$ \\
\hline Materials consumption $(\mathrm{kg})$ & $-4,500$ & 7,875 & 3,375 \\
\hline Energy use (MJ) & $-6,750$ & 11,800 & 5,050 \\
\hline Emissions (kg CO2-e) & $-2,400$ & 4,175 & 1,775 \\
\hline Solid waste production (kg) & -310 & 2,440 & 2,750 \\
\hline
\end{tabular}

the financial and environmental impacts are combined, irrespective of whatever relative impact weightings are chosen for these two (Bengtsson, Howard, \& Kneppers, 2010), the A form is preferable. For the A form, because of the pre-thought alteration, compared to the NA form, there is a reduction in materials consumption, energy use, emissions and solid waste production.

\subsection{Social analysis}

The A form largely maintains the owner's level of comfort during alteration through avoidance of vacating the house, and rental of temporary accommodation (Edwards \& Turrent, 2000). The presence of the owner, however, during the alteration work exposes the owner to some work-generated dust, vibration and noise, but through appropriate design and scheduling at time 0 , and site-management at $\mathrm{t}=\mathrm{T}$, these can be minimised. The NA form also generates dust, vibration and noise that impacts workers and neighbours. The A form will involve a shorter site time at $t=T$, because of pre-planning and design features included at time 0 . This reduces the extent of any inconvenience to the owner and neighbours. 
Social issues that are regarded in this case example as being different between the A and NA forms are noted in Table 4. Only those issues that can be dealt with using SLCA are considered here. In other situations there may be different lists, but their evaluation would be along similar lines to those presented here; it is the methodology, not the numbers, which is being emphasized here. Issues, for example, related to age, health, disability and access to resources may need evaluating in other situations.

With the same scope and unit processes as defined in the LCA, the relevant inventory flows examined are shown in Figure 4.

Using data from RSMeans (2015), together with information from builders, engineers, tradespeople and industry representatives, the estimates of differences in inventory flows between the A and NA forms follow. Worker employment is measured in total worker hours (hours per worker multiplied by number of workers). Safety incidents are expressed as a frequency, namely the number of injury occurrences per hours worked by all workers (AS1885.1). Health damage due to exposure to construction noise varies with activity-equivalent-continuous-noise level (in decibels, $\mathrm{dB}$ ) and number of exposure hours (hours

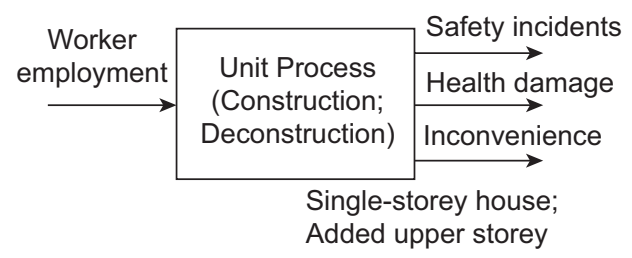

Figure 4. Unit processes and inventory flows for the SLCA per person multiplied by the number of affected people) (BSI, 2009), and has units of dBh. (Activity-equivalentcontinuous-noise level is defined as the sound pressure level determined at a distance of $10 \mathrm{~m}$ from, and over the period of, a given activity - BSI, 2009.) Inconvenience to people during construction implies disruption.

These are summarised in Table 5; the background assumptions are not included here because of space limitations, but they available from the authors. In the absence of an agreed set of impact categories (Benoît et al., 2010), the social impacts are here considered to be the same as the inventories.

The deliberately built-in A form can be seen to be generally better than the non built-in NA form against social impacts, except employment. This would imply that when all impacts (financial, social, environmental) are combined, the A form will be preferable for most chosen relative impact weightings.

\subsection{Sustainability}

It is demonstrated that the built-in A form is generally better than the non built-in NA form according to financial, environmental and social impacts. Accordingly, the A form would be considered a more sustainable alternative, irrespective of how the impacts are weighted relatively or dealt with collectively (Carmichael, 2013).

Environmental and social criteria enhance the financial value of deliberate built-in flexibility in houses.

The sustainability argument in favour of the deliberately built-in A form over the non built-in NA form is not strongly influenced by whether the analysis is carried out from the owner's viewpoint or the community's

Table 4. Comparison of social issues

\begin{tabular}{|c|c|c|}
\hline Time & A - Built-in form & NA - Non Built-in form \\
\hline $\mathrm{t}=0$ & $\begin{array}{l}\text { More construction time - dust, noise, vibration, } \\
\text { neighbourhood disturbance, potential for accidents }\end{array}$ & Lower paid hours for workers \\
\hline $\mathrm{t}=\mathrm{T}$ & $\begin{array}{l}\text { Owner's exposure to dust, noise and vibration } \\
\text { Lower paid hours for workers }\end{array}$ & $\begin{array}{l}\text { Temporary displacement of occupants; temporary } \\
\text { rental elsewhere } \\
\text { Poorer design for people flow within the house } \\
\text { Slightly less attractive aesthetics } \\
\text { More construction time - dust, noise, vibration, } \\
\text { neighbourhood disturbance, potential for accidents } \\
\text { Larger site clean-up post-deconstruction and } \\
\text { construction }\end{array}$ \\
\hline
\end{tabular}

Table 5. Differences (NA - A) in social impacts

\begin{tabular}{|l|c|c|c|}
\hline \multicolumn{1}{|c|}{ Social impact } & At $\mathrm{t}=0$ & At $\mathrm{t}=\mathrm{T}$ & Combined $\mathrm{t}=0$ and $\mathrm{T}$ \\
\hline Worker employment $(\mathrm{h})$ & -160 & 200 & 40 \\
\hline Safety incidents (number of injuries per $\left.10^{6} \mathrm{~h}\right)$ & -0.0053 & 0.0066 & 0.0013 \\
\hline Health $(\mathrm{dBh})$ & $-49,200$ & 50,640 & 1,440 \\
\hline Inconvenience $(\$)$ & 0 & 8,500 & 8,500 \\
\hline
\end{tabular}


viewpoint. However, the owner's decision making could be anticipated to be strongly influenced by personal interest and personal values.

\section{Discussion}

The architecture literature suggests that there is value in flexibility, but has stopped short in quantifying this value. The related civil engineering infrastructure literature has attempted some quantification of value through the use of financial options analogies. However such analogies have been called into question, in particular with establishing equivalent volatilities, which do not exist in infrastructure, deterministic exercising and other modelling assumptions (Carmichael et al., 2011). Separately, conventional deterministic discounted cash flow analysis cannot be used because it does not allow for future uncertainty, while decision trees fail to capture future decision changes. This paper, by contrast, uses a rational quantitative analysis that gives the financial value of flexibility, with social and environmental matters evaluated along life cycle assessment lines. Financial, social and environmental considerations are looked at singly and combined.

The validity of the approach rests on accepting probabilistic discounted cash flow analysis as a model for the time value of costs, and life cycle assessment thinking for environmental and social issues. The approach is free of any particularities of building or change type, but naturally the specific numbers change in different applications.

It is emphasized that the conclusions reached in the given case study example are based on certain design assumptions, one style of building and material choice, and a given country. Accordingly, the methodology, rather than the absolute numbers, is emphasised in the paper. The numbers are indicative, but will change with different reader assumptions and geographical locations. Other forms of built-in flexibility are possible, and with house practices location-dependent, there are too many variables to enable any generalisation. The methodology given in this paper is general and it carries over to other situations and locations, but the actual numbers and building practices will not.

The average time between people moving houses in Australia is approximately 10 years (ABS, 2011). Deliberately building in flexibility, for the assumptions considered, was shown to be financially viable up to this time period, but not longer time periods unless the interest rates are low. Social and environmental impacts increase the viability. However, it is unclear as to how house owners will interpret the favourable financial, social and environmental impacts and what unstated decision making processes house owners go through.

The resale value of a house containing deliberate builtin flexibility should in principle be greater than a house without such a feature. However, it is unclear as to what value the market would place on this; to a buyer considering a possible future alteration, its worth follows Figures 1 and 2, but in any negotiation between buyer and seller this information would be unknown to the seller.
Examining the background to Equation (1), the deliberate built-in flexibility financial value increases with uncertainty about future costs. The predominant source of this uncertainty lies in the building work method adopted and the scope of the work, with lesser uncertainty due to material choice. The building work might typically be undertaken on a cost reimbursable basis because an existing house is being modified and because of the poor scope definition, rather than on a fixed price basis as is more common with new houses, which have good scope definition. The final outcome cost for cost reimbursable work is never definite.

The uncertainty in the cost estimates could be assumed to grow with time, on the basis that estimates further into the future are less definite. The calculations show, however, that this uncertainty has to be much larger than that used in this paper, relative to expected cost value, before it starts to change the broad conclusions in the case example. Similarly, the value placed on social and environmental impacts could be anticipated to increase with time, as people readjust their value systems in line with increasing public sustainability imperatives.

\section{Conclusions}

The paper showed a method for valuing deliberately built-in flexibility in houses. This was demonstrated on a case example, using actual data, involving a typical Australian house conversion. The built-in flexibility form was compared with the non built-in flexibility form. For the case example, financial viability for built-in flexibility was demonstrated for smaller interest rates and smaller times to alteration, but not for larger interest rates and/or time to alteration. The case example made certain assumptions, and changing these assumptions will alter the calculated values; however the methodology of Section 2 remains unchanged.

Whether building in flexibility is viable or not, from the house owner's financial viewpoint, cannot be said in general terms, but rather requires an individual analysis for each situation. No general conclusions on the viability can be drawn, but rather depend on the specifics of each situation. In some situations, deliberate built-in flexibility will be worthwhile, while in others it may not. Intangibles and sustainability arguments increase the viability of building in flexibility but at the present time, based on numerous observations by the authors, it is believed that few house owners would apply much weighting to these intangibles and sustainability compared to the financial aspects.

The architecture literature suggests that there is value in flexibility, but has stopped short in quantifying this value (Gann \& Barlow, 1996; Slaughter, 2001). This paper adds to current literature by providing an analysis that gives the value of any flexible building infrastructure. The approach will be useful to the construction industry and building owners contemplating prolonging the useful life of buildings through alteration over time. The method given in this paper has broader applicability than detached housing, and extends to flexibility analysis generally, for 
example to conversion of buildings generally to alternative usages, and even including urban "planning" changes.

Further research. Fine tuning of deliberately built-in flexibility features is possible, such that built-in flexibility might become more commonplace. The analysis given in Section 2 of this paper will not change, but the numerical values, such as given in Section 3, will. With creative thought, built-in flexibility could become the norm.

In the paper it was stated that creative design is involved in how flexibility might be incorporated in order to produce the best outcome for the owner. Future research might look at how creative design might be captured in the analysis, along the housing valuation lines of de Jonge (2005).

It is unclear whether a house with built-in flexibility would be more attractive to the market, and whether the market would pay more for such a house. A study on this could clarify the situation.

It is anticipated that different people would have different perceived utility of built-in flexibility, depending for example on whether a person is attached to a location or a house, or not. A person's age would also affect this utility, with younger people being more mobile as their workplace changes, and older people thinking of family stability. The utility of built-in flexibility could be researched.

Specific reasons why people modify houses and what is modified are not explored in the paper, nor are the socio-economic backgrounds of the people and their conversions. Societal and demographic aspects may hinder or support the capacity to do alterations. There may be unfavourable issues that prevent alterations or limit the capacity to do alterations. This could be the subject of future research.

The social and environmental issues contain intangibles. An attempt could be made to establish values that people put on these intangibles. Generally, it is anticipated that intangibles will increase the viability of designing in flexibility features.

The biggest argument in favour of having pre-thought flexibility may be an aesthetic one. The NA form always looks like a house altered or converted, while the A form can seamlessly change the existing building. The aesthetic value of the A form over the NA form needs exploring.

An alternative view is to regard the choice at $t=0$ between the deliberate built-in A form and the NA form as an exercise in risk management. Here risk is used in the sense of being a function of outcome likelihood and outcome magnitude (Carmichael, 2016b). This approach would require house owner estimates of future probabilities that alternative housing will be required, and probabilities associated with the timing of the future alteration, or average community figures could be used. The applicability of risk management thinking to house owners could be explored.

The case example and house type and conversion apply to typical Australian practices. It is recognised that house practices vary around the world, and while the methodology of the paper will apply to all house types, the conclusions are location-specific, and differences in house types and practices could be explored.
The financial calculations given in this paper have broader applicability, and extend beyond houses to infrastructure generally, as well as to urban "planning" and construction.

\section{References}

ABS. (2011). 4102.0 - Australian social trends, Dec 2010. Australian Bureau of Statistics, Canberra. Retrieved from http:// www.abs.gov.au/AUSSTATS/abs@.nsf/Lookup/4102.0Main+F eatures30Dec+2010

ABS. (2012). 1301.0 - Year Book Australia, 2012 - Housing and life cycle stages. Australian Bureau of Statistics, Canberra. Retrieved from http://www.abs.gov.au/ausstats/abs@.nsf/Looku p/1301.0Main+Features1322012

Arge, K. (2005). Adaptable office buildings: theory and practice. Facilities, 23(3/4), 119-127. https://doi.org/10.1108/02632770510578494

AS1885.1. (1990). Worksafe Australia National Standard: Workplace Injury and Disease Recording Standard. Standards Association of Australia, Sydney.

Bengtsson, J., Howard, N., \& Kneppers, B. (2010). Weighting of environmental impacts in Australia. The Building Products Innovation Council (BPIC), Sydney.

Benoît, C., Norris, G. A., Valdivia, S., Ciroth, A., Moberg, A., Bos, U., Prakash, S., Ugaya, C., \& Beck, T. (2010). The guidelines for social life cycle assessment of products: just in time!. International Journal of Life Cycle Assessment, 15(2), 156-163. https://doi.org/10.1007/s11367-009-0147-8

BSI. (2009). Code of practice for noise and vibration control on construction and open sites, Part 1: Noise. British Standards, BS 5228-1, UK.

Carmichael, D. G. (2006). Project planning, and control. London: Taylor \& Francis. https://doi.org/10.4324/9780203640166

Carmichael, D. G. (2013). Problem solving for engineers. Boca Raton: CRC Press. https://doi.org/10.1201/b14955

Carmichael, D. G. (2014). Infrastructure investment - an engineering perspective. Boca Raton: CRC Press. https://doi.org/10.1201/b17654

Carmichael, D. G. (2015). Incorporating resilience through adaptability and flexibility. Civil Engineering and Environmental Systems, 32(1-2), 31-43.

https://doi.org/10.1080/10286608.2015.1016921

Carmichael, D. G. (2016a). A cash flow view of real options. The Engineering Economist, 61(4), 265-288. https://doi.org/10.1080/0013791X.2016.1157661

Carmichael, D. G. (2016b). Risk - a commentary. Civil Engineering and Environmental Systems, 33(3), 177-198. https://doi.org/10.1080/10286608.2016.1202932

Carmichael, D. G., \& Balatbat, M. C. A. (2008). Probabilistic DCF analysis and capital budgeting and investment - a survey. The Engineering Economist, 53(1), 84-102. https://doi.org/10.1080/00137910701864809

Carmichael, D. G., Hersh, A. M., \& Parasu, P. (2011). Real options estimate using probabilistic present worth analysis. The Engineering Economist, 56(4), 295-320.

Conejos, S. (2013). Optimisation of future building adaptive reuse design criteria for urban sustainability. Journal of Design Research, 11(3), 225-242. https://doi.org/10.1504/JDR.2013.056589

Cordell. (2014). Cordell housing building cost guide, 44, 3. Cordell, Sydney.

de Jonge, T. (2005). Cost effectiveness of sustainable housing investments (PhD Thesis). Delft University of Technology, Delft, 
the Netherlands. Retrieved from https://repository.tudelft. nl/islandora/object/uuid\%3A161e8d60-14f3-4f94-b05fc11d9a1fee0f? collection=research

de Neufville, R., \& Scholtes, S. (2011). Flexibility in engineering design. Cambridge: MIT Press.

Edwards, B., \& Turrent, D. (2000). Sustainable housing: principles and practice. London: Taylor \& Francis.

Fänge, A., \& Iwarsson, S. (2005). Changes in ADL dependence and aspects of usability following housing adaptation: a longitudinal perspective. American Journal of Occupational Therapy, 59(3), 296-304. https://doi.org/10.5014/ajot.59.3.296

Friedman, A. (1993). A decision-making process for choice of a flexible internal partition option in multi-unit housing using decision theory techniques: Dordrecht, Kluwer Academic Publishers. https://doi.org/10.1007/978-94-017-1229-3_14

Gann, D. M., \& Barlow, J. (1996). Flexibility in building use: the technical feasibility of converting redundant offices into flats. Construction Management and Economics, 14(1), 55-66. https://doi.org/10.1080/01446199600000007

Gilchrist, A., \& Allouche, E. N. (2005). Quantification of social costs associated with construction projects: state-of-the-art review. Tunnelling and Underground Space Technology, 20(1), 89-104. https://doi.org/10.1016/j.tust.2004.04.003

Gosling, J., Sassi, P., Naim, M., \& Lark, R. (2013). Adaptable buildings: a systems approach. Sustainable Cities and Society, 7, 44-51. https://doi.org/10.1016/j.scs.2012.11.002

Greden, L. V. (2005). Flexibility in building design: a real options approach and valuation methodology to address risk ( $\mathrm{PhD}$ thesis). Massachusetts Institute of Technology, Cambridge.

Guma, A. C. (2008). A real options analysis of a vertically expandable real estate development (Masters thesis). Massachusetts Institute of Technology, Cambridge.

Heath, T. (2001). Adaptive reuse of offices for residential use. Cities, 18(3), 173-184. https://doi.org/10.1016/S0264-2751(01)00009-9

Hong, T., Ji, C., Jang, M., \& Park, H. (2014). Assessment model for energy consumption and greenhouse gas emissions during building construction. Journal of Management in Engineering, 30(2), 226-235. https://doi.org/10.1061/(ASCE)ME.1943-5479.0000199

ISO (2006). ISO 14040:2006 Environmental Management - Life Cycle Assessment: Principles and Framework, ISO 14044:2006 Environmental Management - Life Cycle Assessment - Requirements and Guidelines. International Organization for Standardization ISO, Geneva.

Karol, E. (2007). Inclusive design and the new home market: the West Australian situation. Architectural Science Review, 51(1), 80-83. https://doi.org/10.3763/asre.2008.5111

Kats, G., Alevantis, L., Berman, A., Mills, E., \& Perlman, J. (2003). The costs and financial benefits of green buildings. Sustainable Building Task Force, Sacramento, California.

Kendall, S. (1999). Open building: an approach to sustainable architecture. Journal of Urban Technology, 6(3), 1-16. https://doi.org/10.1080/10630739983551

Langston, C. (2011, January). On archetypes and building adaptive reuse. $17^{\text {th }}$ Annual Pacific Rim Real Estate Society (PRRES) Conference (12 p.). Pacific Rim Real Estate Society, Gold Coast, Queensland.

Langston, C. (2013). The role of coordinate-based decision making in the evaluation of sustainable built environments. Construction Management and Economics, 31, 62-77. https://doi.org/10.1080/01446193.2012.738920

Langston, C., Wong, F. K. W., Hui, E. C. M., \& Shen, L. Y. (2008). Strategic assessment of building adaptive reuse opportunities in Hong Kong. Building and Environment, 43(10), 1709-1718. https://doi.org/10.1016/j.buildenv.2007.10.017
Langston, C., Yung, E. H.-K., \& Chan, E. H.-W. (2013). The application of ARP modelling to adaptive reuse projects in Hong Kong. Habitat International, 40, 233-243. https://doi.org/10.1016/j.habitatint.2013.05.002

Lehmann, A., Zschieschang, E., Traverso, M., Finkbeiner, M., \& Schebek, L. (2013). Social aspects for sustainability assessment of technologies - challenges for social life cycle assessment (SLCA). The International Journal of Life Cycle Assessment, 18(8), 1581-1592. https://doi.org/10.1007/s11367-013-0594-0

Moffatt, S., \& Russell, P. (2001). Assessing the adaptability of buildings, IEA Annex 31: Energy-related environmental impact of buildings. Canada Mortgage and Housing Corporation, Ottawa.

Moon, H., Hyun, C., \& Hong, T. (2014). Prediction model of emission for residential buildings in South Korea. Journal of Management in Engineering, 30(3), 1-7. https://doi.org/10.1061/(ASCE)ME.1943-5479.0000228

NCSU. (2013). Universal design: housing for the lifespan of all people. Centre for Universal Design, North Carolina State University, Raleigh, North Carolina.

Palmer, J., \& Ward, S. (2013). Housing of the future: the liveable and adaptable house. Retrieved from http://www.yourhome. gov.au/housing/livable-and-adaptable-house

Rawlinsons, W. A. (2015). Australian construction handbook (33rd ed.). Rawlinsons, Perth, Western Australia.

Reardon, C. (2013). Lightweight framing. Australian Government. Retrieved from http://www.yourhome.gov.au/materials/lightweight-framing

Remøy, H., de Jong, P., \& Schenk, W. (2011). Adaptable office buildings. Property Management, 29(5), 443-453. https://doi.org/10.1108/02637471111178128

RSMeans. (2015). RSMeans building construction cost data. RSMeans Construction Publishers and Consultants, Norwell, Massachusetts.

Sawacha, E., Naoum, S., \& Fong, D. (1999). Factors affecting safety performance on construction sites. International Journal of Project Management, 17(5), 309-315. https://doi.org/10.1016/S0263-7863(98)00042-8

Schneider, T., \& Till, J. (2005). Flexible housing opportunities and limits, Theory, 9(2), 157-166. https://doi.org/10.1017/S1359135505000199

Slaughter, E. S. (2001). Design strategies to increase building flexibility. Building Research and Information, 29(3), 208-217. https://doi.org/10.1080/09613210010027693

Surbeck, C. Q., \& Hilger, H. (2014, 1-5 June). Social sustainability and important indicators in infrastructure. World Environmental and Water Resources Congress (pp. 2078-2093). Portland, Oregon. https://doi.org/10.1061/9780784413548.208

Till, J., \& Schneider, T. (2005). Flexible housing the means to the end, Theory, 9(3), 287-296. https://doi.org/10.1017/S1359135505000345

UNEP/SETAC. (2009). Guidelines for social life cycle assessment of products. United Nations Environment Programme / Society of Environmental Toxicology and Chemistry, Gent. Retrieved from www.unep.fr/shared/publications/pdf/dtix1164xpaguidelines_slca.pdf

Wilkinson, S. J. (2011). The relationship between building adaptation and property attributes ( $\mathrm{PhD}$ thesis). Deakin University, Waurn Ponds, Victoria.

Wilkinson, S. J., James, K., \& Reed, R. (2009). Using building adaptation to deliver sustainability in Australia. Structural Survey, 27(1), 46-61. https://doi.org/10.1108/02630800910941683

Zhang, N. (2010). Applying option thinking in long term infrastructure investment: the case of commercial real estate (Masters thesis). Massachusetts Institute of Technology, Cambridge. 